\title{
Embryo sac haustorium in Dryas octopetala L. (Rosaceae)
}

ROMANA CZAPIK

Department of Plant Cytology and Embryology, Jagellonian University, Grodzka 52, 31-044 Kraków, Poland

(Received: July 11, 1986. Accepted: October 8, 1986)

\begin{abstract}
The embryo sac haustorium found in Dryas octopetala L. from the Tatra Mts is the first record of its occurrence in Rosaceae. At the eight-nucleate stage of the embryo sac, the antipodal end of the central cell began to grow into a narrow caecum filled with dense cytoplasm and elongated in the chalazal direction leaving the three antipodals in situ. The haustorium enlarged and lost its characteristic shape after the period of fertilization. Finally, the embryo sac occupied almost the whole length of the ovule. Situated at its chalazal end there was either dense cytoplasm with a group of endosperm nuclei or dense, grainy cytoplasm only, if fertilization had not taken place.
\end{abstract}

Key words: Dryas octopetala, Rosaceae, embryo sac haustorium

\section{INTRODUCTION}

Several haustorial structures, performing nutritive functions for the embryo sac or embryo in the ovule have been described. They may be formed by the megaspore, embryo sac, synergid, antipodal, endosperm, suspensor or pollen tube (Schnarf 1929). Maheshwari (1963) cited them among embryological characters of taxonomic importance and Poddubnaya-Arnoldi (1976, 1982) regarded the type of haustorium as a phylogenetic and systematic feature. The records, however, are often inadequate. That is why Davis (1966) expressed an opinion that far more information is needed to assess the taxonomic significance of endosperm haustoria, 
on which the data, on the other hand, are more numerous as compared with the other types. In such a state of our knowledge in this field every new observation will be useful for a better understanding of the problem as well as for filling the existing gaps in the embryological diagrams of the taxa.

In some families more than one type of haustorium has been reported. For example embryo sac and endosperm haustoria often occur together in the same family and even in the same species and it happens that the embryo sac haustorium turns into the endosperm one, e.g. in Agrostema githago (Rocén 1927), Leptomeria (Ram 1959), or Cansjera rheedii (Swa my 1960). Three types are mentioned in Saxifragaceae and Lentibulariaceae and four in Crassulaceae and Santalaceae (Poddubnaya-Arnoldi 1982).

In the embryological diagram of the family Rosaceae, two types of haustoria are noted. They are formed by megaspores in Potentilla (Rutishauser 1945) or by endosperm in Prunus and Rubus (lit. Mandrik and Petrus in Yakovlev 1985). The present report adds a third type of haustorium to the embryological characteristics of Rosaceae: the embryo sac haustorium found in plants of Dryas octopetala from the Tatra Mts.

\author{
MATERIAL AND METHODS
}

The observations were performed on diploid plants of Dryas octopetala from four sites in the Tatra Mts: Boczań (1224 m a.s.1.), Skupniów Upłaz (1377 m a.s.l.), Jasiowe Turnie (c. $1100 \mathrm{~m}$ a.s.1.) and Dolina Małej Łąki (1000 $\mathrm{m}$ a.s.l.), as well as from the collection of the Botanical Gardens of the Jagellonian University, Cracow. Part of the material from Boczan, Jasiowe Turnie and the Botanical Gardens was examined previously when the variability of the functional macrospore and the type of embryo sac in Dryas octopetala was studied (Czapik 1986) and for the purpose of the present examination new material was added. The plants from Boczan and the Botanical Gardens were examined during two seasons: 1984 and 1985. The experimental emasculation and isolation of flowers was carried on the plants growing in the Botanical Gardens. Altogether, ovules with haustoria from 32 flowers were analysed. They contained eight- and seven-nucleate embryo sacs or embryo sacs with a young embryo and nuclear endosperm.

Flower buds and flowers of various age were fixed in acetic-alcohol (1:3) and embbeded in paraffin. Microtome slides, 10-15 $\mu \mathrm{M}$ thick, were stained in Heidenhain's haematoxylin, combined with PAS or ruthenium red. 


\section{RESULTS}

The variability of functional megaspore in Dryas octopetala was connected, among others, with the variability of the embryo sac type (Czapik 1986). In the examined plants monosporic embryo sacs of the Polygonum type prevailed, while the bisporic ones of the Allium and Scilla type occurred only sporadically. This fact, however, did not influence the structure of the adult embryo sacs, which did not show any pronounced abnormalities. The embryo sacs with eight nuclei were normally organized, having comparatively large egg cells, two synergids smaller then the egg, three small antipodals and two polar nuclei between the egg apparatus and antipodals. The secondary nucleus, after its formation, was situated near the egg cell (Figs. 1, 2, 7); later it was visible in the antipodal region of the embryo sac. In the unfertilized embryo sacs the secondary nucleus lay somewhere in the micropylar part of the embryo sac, which expanded along the almost whole length of the ovule at that time.

The organized embryo sac was short and comparatively wide (Fig. 1). It occupied ca $1 / 3$ of the length of the ovule before the haustorium-formation, which started at the stage of two unfused polar nuclei. In this period the central cell developed a narrow caecum in the vicinity of the antipodals (Fig. 3). The antipodals themselves were left in situ and the caecum grew towards the chalazal region of the ovule (Fig. 8). The growing end of the haustorium was filled with dense, deeply stained cytoplasm (Figs. 2, 3, 9, 10). After the nuclear fusion, the secondary nucleus was sometimes situated on the level of the antipodals near the mouth of the caecum. In a few ovules it was visible in the caecum itself and then the haustorium was still short and it was not clear whether the secondary nucleus was fertilized or not.

There are two characteristic features of the haustorium in Dryas octopetala. The first is the straight growth of the haustorium towards the chalaza (Figs. 2, 3, 8). Its dense, grainy segment of cytoplasm was recognizable both in old, unfertilized embryo sacs in emasculated and isolated flowers from the Botanical Gardens and in the open-pollinated flowers of the plants from Boczan when their fertilization was prevented by low temperature and snowfall in the middle of June 1985 (Figs. 6, 10).

The second feature is the undisturbed position of the antipodals in the embryo sacs with the developing haustorium. The outgrowth of the central cell bypassed them laterally. The growing haustorium, narrow at first, started to enlarge soon. The border-line between the formerly short and relatively wide embryo sac and the narrow haustorium disappeared. It was marked only by the remnants of the degenerating antipodals laying in their previous position, now belonging to the micropylar region of the long embryo sac (Fig. 4). 
In the fertilized embryo sacs, at the nuclear stage of endosperm, several nuclei gathered in the dense cytoplasm at the chalazal end of the endosperm body (Fig. 5). Cell-formation was not observed so it was not known whether they persisted longer in the state of free nuclei forming a kind of simple endosperm haustorium at the end of cellular tissue. The mature seed contained embryo and endosperm tissue without any remainder of free nuclei.

As it is described above, the development of the haustorium began at the eight-nucleate stage of the embryo sac. Sometimes a short caecum was visible in an embryo sac with the secondary nucleus - the result of a delay of the haustorium-formation or its slower growth. In some ovules the development of the haustorium could be retarded indeed, because it was not present at the stage of the secondary nucleus in such flowers whose other ovules contained embryo sacs with short or long haustoria. The differences ranged from 35 to $100 \%$ of emryo sacs with haustoria within a flower before fertilization. Nevertheless, old embryo sacs were long and in many of them remnants of antipodals in the lateral position in the upper part of the embryo sac were recognizable - the feature strictly connected with the growth of the haustorium.

The embryo sac haustorium in Dryas octopetala is of a simple type. As a structure formed by the central cell, the haustorium enlarges the volume of the embryo sac digesting the ovular tissue below, making ready the space necessary for the embryo and endosperm development.

\section{DISCUSSION}

The occurrence of embryo sac haustoria is mentioned in the embryological characteristics of ca 20 families of Angiospermae out of the 438 covered by the monograph by Poddubnaya-Arnoldi (1982). The course of their development varies, depending on the time and place of the beginning of the process, the shape and final fate of the structure. The development may start at the bi-, four- or eight-nucleate stage of the embryo sac. When it begins in the organized embryo sac, as in Dryas octopetala, it is, strictly speaking, an outgrowth of the central cell. The time of the formation differentiates it from the endosperm haustorium into which some of the embryo sac haustoria pass in due time. The embryo sac haustorium is always formed before, the endosperm one after fertilization (Schnarf 1929, Maheshwari 1950). The haustorial growth of the central cell is localized mostly at the chalazal, rarely at the micropylar pole of the embryo sac, sometimes at each of them. Lateral haustoria are the rarest in embryological reports. When the haustorium grows at the chalazal end 
PLATE I
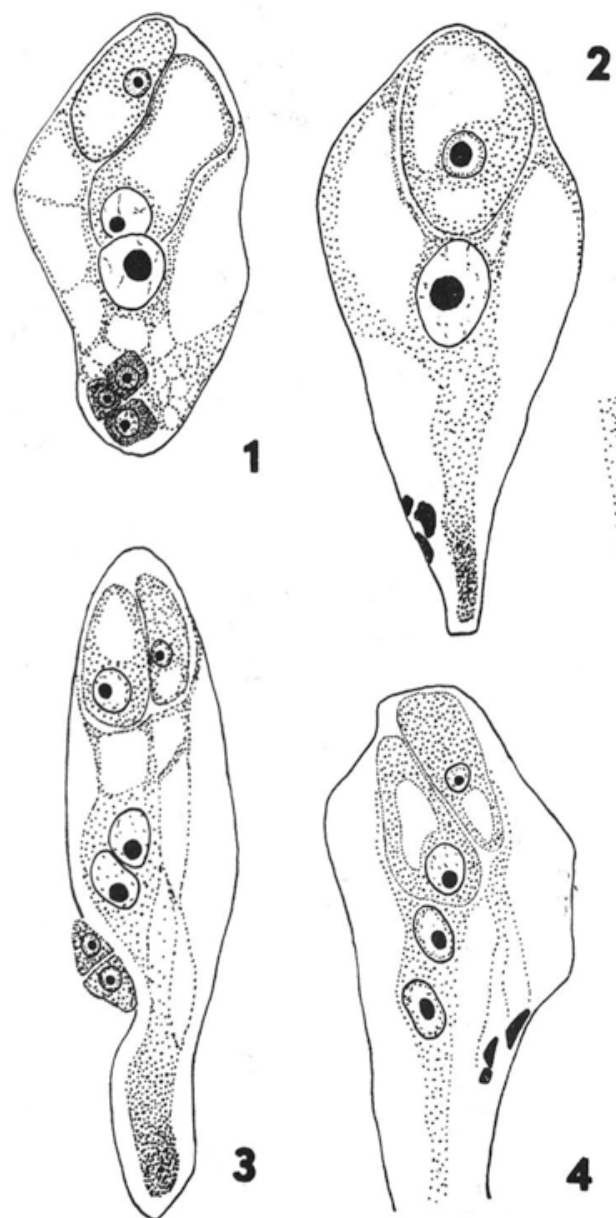

2
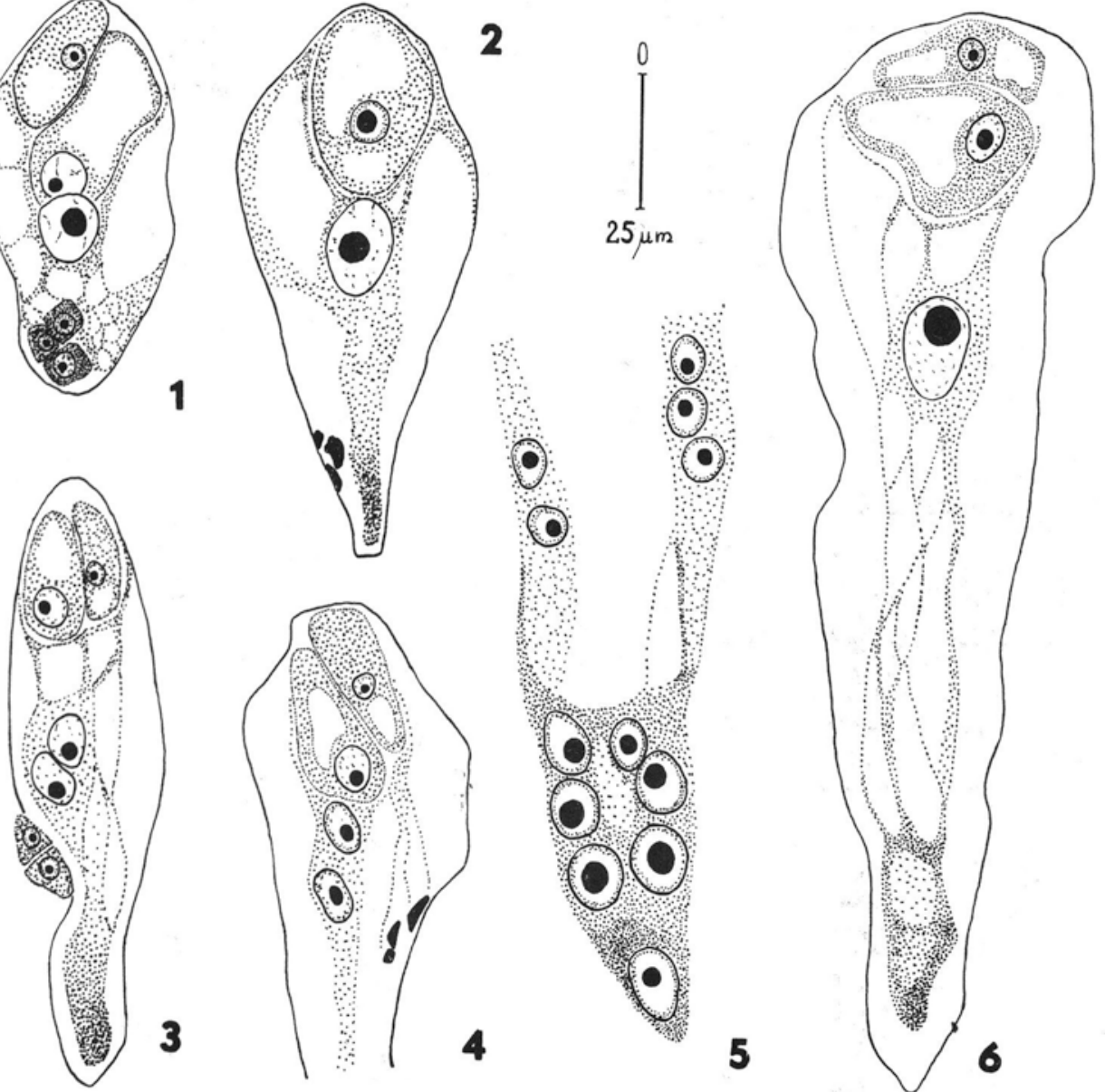

Figs. 1-6. Dryas octopetala: 1 - embryo sac with the secondary nucleus, no haustorium-formation; 2 - short haustorium, degenerating antipodals in the lateral position; 3 - formation of the haustorium at the stage of polar nuclei; 4- fertilized embryo sac with two nuclei of endosperm, degenerating antipodals; 5 - endosperm at the chalazal end of the embryo sac; 6 - adult embryo sac from an unfertilized flower 


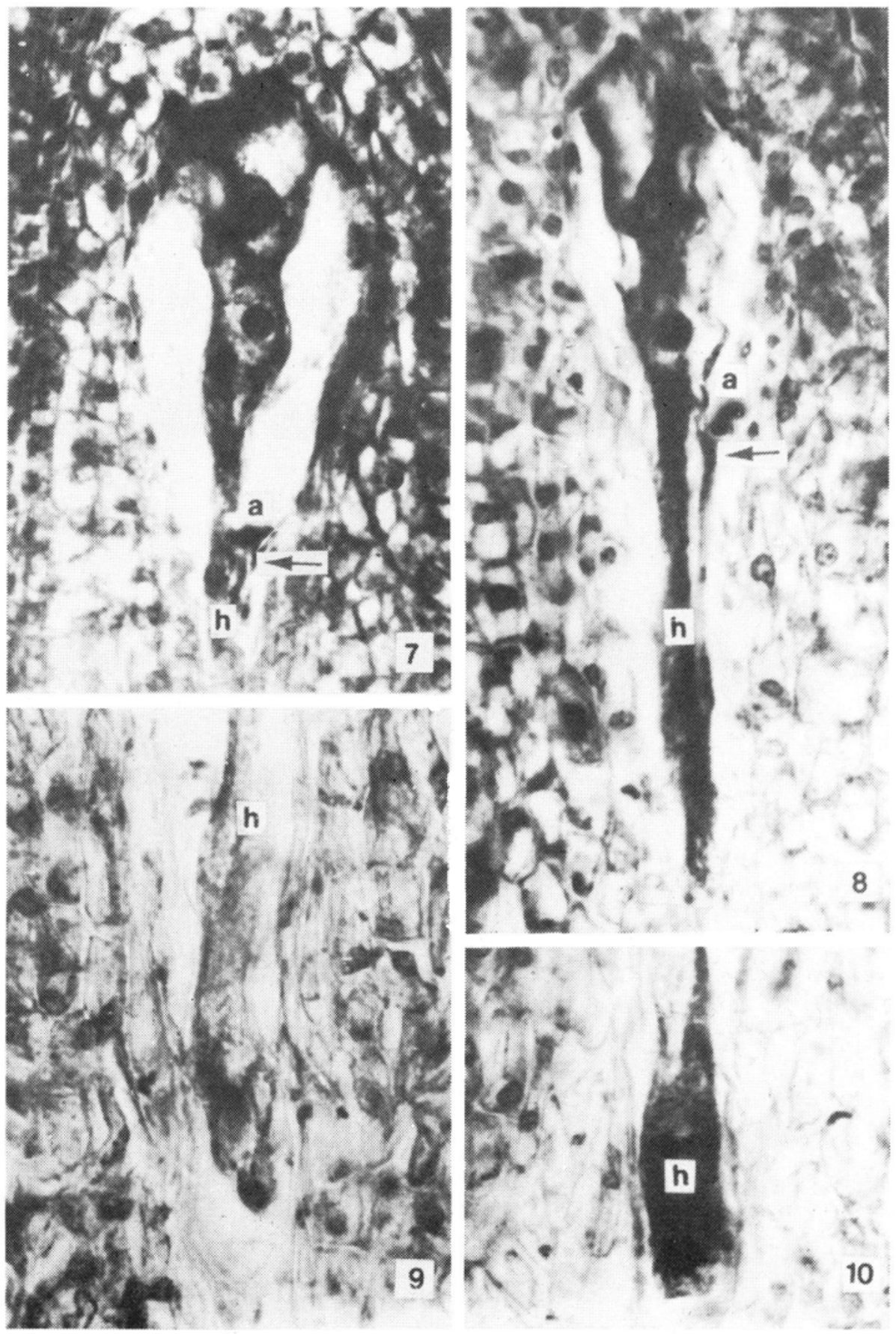

Figs. 7-10. Dryas octopetala: 7 - embryo sac with a short haustorium below the antipodals; 8 - straight growth of the haustorium; 9 and 10 - the end of the growing haustorium. a - antipodals, $h$ - haustorium, arrows point to the border between the embryo sac and the haustorium. $\times 700$ 
of the embryo sac, the antipodals are left behind in their original position, as in Drays octopetala. An exception is the haustorium in Cansjera rhedii. In this plant antipodal cells are not formed and free antipodal nuclei migrate into the chalazal caecum (Swamy 1960).

The embryo sac haustorium in Dryas octopetala neither curves nor branches. Its active growth is seen especially at the beginning, when the size differences between the width of the haustorium and of the upper part of the embryo sac are well visible. The endosperm nuclei fill the whole of its cavity after fertilization. The chalazal group of the nuclei can hardly be taken for an endosperm haustorium, especially as cell-formation in the endosperm was not examined.

It seems that the speed of the development of the haustorium in Dryas octopetala may be influenced by external factors, e.g. decrease of temperature, which occurs often in natural sites of the plant in the mountains. Such a hypothesis might, to some extent, explain the retardation of the process within a flower, especially when the age differences between the ovules and their embryo sacs are not detectable under the microscope.

The formation of the haustorium in Dryas octopetala may be interpreted as a specific process leading to the increase of the volume of the embryo sac before the development of embryo and endosperm. Simultaneously the absorbtive surface of the embryo sac increases, what enhances the supply of nutrients (Masand and Kapil 1966).

Acknowledgement

Thanks are due to the Director of the Botanical Gardens, Jagellonian University, Doc. Dr. Hab. K. Szczepanek for the kind permission to take plants from the Garden collection for the study.

\section{REFERENCES}

Czapik R., 1986. Mono- and bisporic embryo sacs in Dryas octopetala L. (Rosaceae). Acta Biol. Cracov. ser. Bot. 28: 31-38.

Davis G., 1966. Systematic embryology of the angiosperms. John Willey, New York. Maheshwari P.. 1950. An introduction to the embryology of angiosperms. Mc. Grew Hill, New York.

Maheshwari P., 1963. Embryology in relation to taxonomy. Vistas in Botany 4: 55-96. Masand P., Kapil R. N., 1966. Nutrition of the embryo sac and embryo. - A morphological approach. Phytomorphology 16: 158-175.

Poddubnaya-Arnoldi V. A., 1976. Tsitoembriologiya pokrytosyemyennykh rasteniy. Nauka, Moskva.

Poddubnaya-Arnoldi V.A., 1982. Kharaktyeristika syemyeystv pokrytosyemyennykh rastyeniy po tsitoembriologicheskim priznakam. Nauka, Moskva.

Ram M., 1959. Morphological and embryological studies in the family Santalaceae. III. Leptomeria R. Br. Phytomorphology 9: 20-33. 
Rocén T., 1927. Zur Embryologie der Centrospermen. Diss. Uppsala, pp. 1-184.

Rutishauser A., 1945. Zur Embryologie amphimiktischer Potentillen. Ber. Schweiz. Bot. Ges. 55: 19-32.

Schnarf K., 1929. Embryologie der Angiospermen. Handbuch der Pflanzenanatomie. II.

2. Archegoniaten. Gebrüder Borntraeger, Berlin.

Swamy B. G. L., 1960. Contribution to the embryology of Cansjera rheedii. Phytomorphology 10: 397-409.

Yakovlev M.S. (ed.), 1985. Comparative embryology of flowering plants. Brunelliaceae-Tremandraceae. Nauka, Leningrad. (in russ.).

\section{Haustorium woreczka zalążkowego u Dryas octopetala L. (Rosaceae)}

\section{Streszczenie}

Haustorium woreczka zalążkowego opisane u Dryas octopetala z Tatr jest nową cechą embriologiczną rodziny Rosaceae. Zaczyna się ono tworzyć w stadium ośmiojądrowym woreczka zalążkowego jako wąskie uwypuklenie komórki centralnej z boku antypod, pozostawionych in situ przez rosnące haustorium. Uwypuklenie wypełnione gęstą, ziarnistą cytoplazmą rośnie w kierunku chalazalnym, rozszerza się w okresie dojrzałości woreczka zalążkowego do zapłodnienia, a następnie wypełnia jądrami endospermy grupującymi się dość licznie w gęstej cytoplazmie na szczycie chalazalnym. W równie długich, niezapłodnionych woreczkach zalążkowych odcinek szczytowy wyróżnia się nadal gęstą, ziarnistą cytoplazmą, podobną do tej, która wypełnia młody, rosnący uchyłek haustorialny.

Haustorium woreczka zalążkowego u Dryas octopetala należy zatem do prostego typu chalazalnego i ma podstawowe znaczenie dla powiększania objętości i powierzchni absorbcyjnej woreczka zalążkowego przed rozpoczęciem rozwoju zarodka i endospermy. 